Journal of English Language Teaching

UNNES

\title{
Teaching strategies: How do teachers in remote area survive during remote
} learning?

\author{
Rini Amelia ${ }^{{ }_{1}}$, Tia Nur Istianah ${ }^{2}$ \\ ${ }^{1}$ Politeknik Negeri Banjarmasin, Indonesia \\ ${ }^{2}$ Institut Agama Islam Cirebon, Indonesia
}

\begin{tabular}{|c|c|}
\hline Article Info & Abstract \\
\hline $\begin{array}{l}\text { Article History: } \\
\text { Received in } 30 \text { June } \\
2021 \\
\text { Approved in } 26 \text { July } \\
2021 \\
\text { Published in } 28 \text { July } \\
2021 \\
\text { Keywords; Teaching } \\
\text { Strategy; Remote Area; } \\
\text { Remote Learning }\end{array}$ & $\begin{array}{l}\text { During the pandemic of COVID-19, remote learning has been very highlighted. This } \\
\text { environment creates huge challenges especially to those teaching in remote areas. Drawing } \\
\text { on them, this descriptive qualitative study aims to explore teaching strategies applied there. } \\
\text { In collecting the data, interviews and questionnaires were given to two English teachers of } \\
\text { a Junior High School in Aranio, Banjar Regency. The results show that they have to face } \\
\text { some challenges such as the limitedness of internet access and low motivated students } \\
\text { when implementing remote learning. Due to this condition, they need to survive by making } \\
\text { some efforts such as creating and using interesting teaching modules, coordinating with the } \\
\text { related parties, carrying out blended learning, conducting home visit and setting up offline } \\
\text { classes because of no possibility for online learning. Through this study, other teachers are } \\
\text { kindly informed on the applicable teaching strategies to create effective remote learning } \\
\text { experiences in remote areas. }\end{array}$ \\
\hline
\end{tabular}

${ }^{\square}$ Correspondence Address:

p-ISSN 2252-6706 | e-ISSN 2721-4532

Jl. Brig Jend. Hasan Basri, Pangeran,

Kec. Banjarmasin Utara, Kota Banjarmasin, Kalimantan

Selalatan, Indonesia 70124

E-mail: rini.thabrani@gmail.com 


\section{INTRODUCTION}

The pandemic of COVID-19 declared as a global pandemic has affected many sectors including education. A number of schools are closed and students are sent home in order to prevent the spread of corona virus. Then the concept of studying from home are newly introduced by the Circular of the Ministry of Education and Culture No. 4 of 2020. Consequently, remote learning becomes a big necessity. Remote learning brings some challenges and urge teachers to find some applicable teaching strategies to deal with it. It is then brought to the surface and highligted since it must be carried out to keep teaching and learning process going. The COVID-19 pandemic does shift face-to-face interaction in physical classroom to remote learning.

Some other significant impacts are also seen in education. The rise of virtual learning contributes to the emergence of several online teaching platforms which soundly offer their free services. Also, a number of webinars, online courses, workshops and trainings starts mushrooming. They all offer feasibility for all educators around the world, including Indonesia.

As an archipelagic country, Indonesia owns special geographical condition in which the infrastructure development is still considered uneven. Consequently, some areas are called developed and others are underdeveloped. Those in developed areas get some feasibility in many aspects of life. They are very familiar with many sophisticated technologies. Meanwhile, those living in underdeveloped areas, also called remote areas, find it difficult to catch up. It is no wonder that the quality of education in developed or urban areas is claimed much better than that of remote areas. This factor also makes some differences and gives certain impacts on the implementation of remote learning during the pandemic of COVID-19.

In regard to remote learning, it is frequently seen as an obvious choice for many students with access limitation (Macintyre \& Macdonald, 2011). In addition, Rizaldi \& Fatimah (2020) state that remote learning is an effective solution to continuing the learning process during the COVID-19 pandemic when it does not allow direct learning in the classroom. Those experts claim the importance of remote learning as one alternative way to implement.

Dealing with remote learning environment, Belastock (2020) says that transitioning a school community to a remote learning environment involves long-range strategic planning, allocation of resources, focused sustainable professional development and equitable access to devices and connectiviy for students. Moreover, Ray (2020) states that remote learning should provide an opportunity for students and teachers to remain connected and engaged with the content while working from their homes. Paolini (2015) adds some points to be concerned in order to create or enhance wellorganized learning such as communication, class environment, students' engagement, teaching material, and teaching strategy.

The previous statements explicitly tell several essential elements should be included when implementing remote learning. It is surely not an easy task for teachers. The necessity for conducting remote learning does challenge teachers especially those teaching in remote areas. As it is known, remote area is a geographic area located far from the city and hard to reach (due to limited means of transportation) and difficult to access because of its geographical conditions (archipelago, mountainous, or swamp areas). Besides, the internet connection and electricity are frequently nowhere to be seen. Drawing on these conditions, they are certainly not capable of doing online activities since they have limited or no access to the internet. This inability may cause other teaching obstacles emerge.

Nevertheless, the teachers must ensure the continuity of teaching and learning activities. They need to make some efforts to deal with the hardships they face. Although all learning activities are not able to be carried out online, the effectiveness of teaching and learning and the expected students' outcomes must be considered by the teacher. What teacher has prepared before teaching can determine the learning results. In conclusion, it is compulsory for teachers to make learning organization or planning before a given class

On the subject of teaching strategy which is also the focus of this study, Paolini (2015) states that teaching strategy can create effective teaching. Besides, (Kistner et al., 2015) argue that teaching learning strategy is one important aspect of the consistenly claimed promotion of self-regulated learning which involves planning, executing, and evaluating learning process. Many educational institutions design their teaching strategy to be used during remote learning because they want the essence of learning to be implemented in remote learning as well.

Concerning teaching strategy, teachers must coordinate well with parents. During remote learning, the students are allowed to learn anytime and anywhere systematically, according to teacher's instructions (Pratiwi \& Chasanah, 2018). In accordance to the learning situation during COVID-19, 
students have to study by the help of their parents. In other words parents take responsibility for their children learning at home. Therefore, parents have the opportunity to observe and evaluate their children learning (Carpenter \& Dunn, 2020).

Besides parents' reliance, the use of technology becomes the most powerful means in current educational condition. Online learning or remote learning is created along with technological advancement. This learning utilizes the internet and sophisticated media that assist its process from explaining the material, giving the task, and also assessing students' competence. According to Munir (2017), online learning is the use of information and communication technology developments in education that can reach all levels of society. Another assumption also states that technology opens up learning opportunities for all students because it helps them to access, provide, and express their knowledge in a variety of ways (Torrey, 2018). In addition, several online platforms for teaching and learning are exposed. A lot of webinars, online trainings and workshops are set up. Those are designed to assist teachers to go through remote learning successfully.

There have been a lot of studies on remote learning done such as Learning with Online Activities: What Do Students Think About Their Experience? by Abdallah in 2009, The Effectiveness of Online Learning: Beyond No Significant Differences and Future Horizons by Nguyen in 2015, The Online Learning Activities during the COVID-19 Pandemic by Lubis and Sari in 2020, etc. Those studies mainly focus on teaching techniques or online classroom activities potentially done when implementing remote learning. But what about teaching strategies used in remote learning settings? How do teachers, especially those in remote areas, survive when they are incapable of conducting online teaching and learning activities? Thus, this present study is significantly conducted to reveal the challenges faced and the teaching strategies applied by remote school teachers during the implementation of remote learning.

\section{METHODS}

The method used in writing this study is descriptive qualitative method, to expose how teachers in remote area survive in remote learning environment during the COVID-19 pandemic. The challenges and teaching strategies applied are two central themes in this study. In order to get rich information regarding what the researchers are looking for, this study was guided by the following questions:

Table 1. List of Interview Questions

\begin{tabular}{cl}
\hline Theme & \multicolumn{1}{c}{ Questions } \\
\hline $\begin{array}{c}\text { Challenges during } \\
\text { implementing remote } \\
\text { learning }\end{array}$ & $\begin{array}{l}\text { During the COVID-19 pandemic, how was the } \\
\text { teaching and learning process going on there? Are you } \\
\text { conducting remote learning? } \\
\text { What are the challenges you face in remote learning } \\
\text { environment? } \\
\text { Based on your experience, what is the biggest obstacle } \\
\text { when implementing remote learning? }\end{array}$ \\
$\begin{array}{c}\text { Teaching strategies applied } \\
\text { in remote area }\end{array}$ & $\begin{array}{l}\text { What has been prepared by the school in } \\
\text { implementing remote learning? } \\
\text { What teaching strategies have you used in remote } \\
\text { learning environment? } \\
\text { In accordance to students' motivation to take part in } \\
\text { this remote learning, what tips have you done to get } \\
\text { their attention and interest during learning process? } \\
\text { Are there any advantages and weaknesses of the } \\
\text { teaching strategies that you have applied? }\end{array}$ \\
\hline
\end{tabular}

\section{Respondents and Instruments}

Those questions, set in a form of questionnaire and interview, were given to two English teachers of Junior High School. These two teachers were selected because the researchers got their phone number and could easily contact them. Thus, it definitely increases the feasibility of this study. They teach at a school which is located in Aranio, one remote area in Banjar Regency, South Kalimantan.

\section{Data collection procedures}

At the beginning, the questionnaire was administered in the form of Google Form to help the researchers to take and organize the responses. Meanwhile, the interviews were addressed in the form 
of semi-structured interviews which were searching for information related to participants' name, age, and also school's name, then followed by the same main research questions mentioned but in a deep review. The data gained from the interviews were taped and transcribed via WhatsApp (WA). This is because our distance between the participants and the researchers is beyond the reach. Collecting the data was held on $27^{\text {th }}$ April 2021, and the data were immediately analyzed after all the data from both techniques were collected.

\section{Data analysis}

A 5-step process that was used to analyze the data includes narrative, coding, interpretation, confirmation, and presentation (Merriam, 1998). In order to increase credibility and validity of the findings, the researchers used data triangulation. Rugg (2010), the chief of UNAID, defines this as the use of a variety of data sources, including time, space, and person in a study. The data obtained from the questionnaires and interview are compared. It is then found out that both data sources yield the same result. The final findings of this study will present the summary of the two central themes of this study in a detailed description.

\section{FINDINGS AND DISCUSSION}

As discussed earlier, the data in this study were obtained from the questionnaires and interviews. The questions are set up to answer two central themes: challenges and teaching strategies applied during implementing remote learning.

\section{Challenges}

Based on the result of the interview and questionnaire, it is found out that their school which is located in Aranio is categorized into a remote area. This is viewed from SK Bupati document of Banjar Regency No.390 of 2013. The teachers, HR and N, state that during COVID-19 pandemic their school has implemented remote learning. They acknowledge that this remote learning environment has challenged them to keep teaching and learning process going well. They also notice that their students seem to be thriving with this new environment.

There is no internet access and electricity here, so we couldn't carry out online teaching and learning activities to implement remote learning. If we have to, we need to find the signal in certain locations such as on the hill or in higher areas. $(\mathrm{N})$

Being far away from the city, it is no wonder that this area has limited or no electricity and no internet access. They said that, although their school has coordinated to some parties such as teachers, a headman, and also students' parents for funding internet data packages, remote learning still could not run well without internet access. This then becomes their main obstacle when implementing remote learning. Consequently, there are no online teaching activities such as video conferences, online quizzes or exercises and even no teaching materials shared online.

Even though they have had workshops on creating videos for teaching, there is no medium to share those with their students. We have to visit their (students) home, door to door, to distribute the learning assignment and evaluation, and we take them back.

\section{Because of the limitedness of the internet access, it is difficult to implement remote learning so that we ask every class representative to take the assignments and learning materials at school. We even had to do face-to-face learning by following the health protocol due to this condition. (HR)}

It could not be denied that the use of media in teaching and learning is very important as tools to enhance the meaning of active learning. However, the implementation of remote learning will use several digital applications to support the learning system. Based on the teacher' statements, it is clear that they lack the main vehicle to run remote learning program. Their students could access education at their home by studying the learning materials given through home visit and face-to-face sessions at school. Blended learning can be held every week, if the internet can be accessed. It is a learning system that combines remote learning with face-to-face learning.

The teachers also argue that they could not pack their online teaching materials with interesting pictures or videos to attract their students. In addition, they could not explain the teaching materials 
and give an assignment to their students online. Meanwhile, English is one subject that really needs teachers'explanations, they add. They believe that this case has triggered their students to be less motivated in studying English in remote learning environment.

Not only those who live in remote area with its limitations, students in downtown also have low motivation during remote learning amid the current COVID-19 pandemic. Students who do not get used to this learning system will get difficulties in following the process. Remote learning could be one new thing for some schools especially those in remote area, and the use of sophisticated technologies is feeling odd for them. Furthermore, other obstacles stated previously such as limited internet access and learning media can trigger students to be less motivated to learn. Then what the main point when implementing remote learning is that the environment needs to be accessible and empowering so that students' motivation in learning could be optimized.

The previous paragraphs illustrate how remote learning activities done in remote area with many challenges that they have to face. In the next section, the researchers explore several teaching strategies applied by the teachers and school in remote area to survive during remote learning.

\section{Teaching Strategies}

The teachers need to respond well and fast to this learning transition. The need to develop teaching strategies for creating good teaching learning and for motivating students to learn online is imperative. Drawing on the challenges faced in remote area, the teachers took several ways to deal with this remote learning environment.

The major challenge that participants mentioned during remote learning was limited or even no internet access. Connections that should be made using online forum, email, and virtual meeting during remote learning cannot work well in their environmental conditions. Therefore, they create selfstudy modules for their students.

\section{What I've done to handle the limited internet access is giving a learning modul to my students, then I will ask them to do the exercise or assignment on it. (HR)}

The teachers said that they pack their materials with some interesting pictures, simple explanations and exercises. Those are designed to help the students to study the materials and motivate students to learn. Interesting and simulating teaching media is one of many factors that influence students' motivation. (Filgona et al., 2020) state that the use of variety teaching methods and aids is needed to revive and maintain students' interest in learning.

Then we coordinate with some parties involving pembakal, paman kapal, and a few teachers living in that village to distribute modules or teaching materials to the students. $(\mathrm{N})$

To regulate their own learning, the teachers distribute the modules and teaching materials to the students and make sure every student has one as their learning source that should be learned at home. They ask paman kapal (the one who controls the small ship/helmsman), pembakal (the head of the village/ headman) and teachers who live in the village to distribute their teaching materials to their students. Since the area is surrounded by water, kapal and kelotok (small local ship) are the means of transportation to get to the area. The students live separately in three different islands there. As the results, headman, helmsman, and the teachers living there work together taking the responsibility to deliver the materials to the students every week.

A module is very important in online or remote learning environment because of its function as an aid for the presentation of the teaching and learning process. Considering students' difficulty to access the internet, providing modules for them can be one of many solutions that are used when materials cannot be delivered through online applications or online learning platforms. The teachers in this remote area just give the instructions on what students should do during the meeting through WhatsApp group. Then students' work will be submitted once a week at school.

Creating learning modules is a simple teaching strategy used during remote learning. Also, teachers could ask their students to explore the content in the modules in any order and at their own pace. For example, the students are asked to describe one of the learning topics in a brief summary with some pictures to complete their own description. This is what the teachers experience when creating a learning module to support remote learning activities. 
Besides distributing learning modules, the participants also stated that they conducted offline classes with a limited number of students. However, it did not last long since the pandemic became rampant and the teaching and learning process was redirected to remote learning. Then, recently they carry out blended learning.

In this pandemic situation, blended learning can be an alternative solution in implementing teaching and learning processes, especially for schools that cannot only depend on online or remote learning system. The learning is not only held through face-to-face interaction at school but also combined with online learning or other media. First of all, what the teachers do is arranging the schedule of face-to-face interaction. The teachers get to standby all day long waiting for the students. Then the students in turn come to consult the teachers on the materials that are hard for them to understand. The implementation of their blended learning must be student-oriented. Therefore, supporting learning videos, textbooks, and other communication media provided by the school are used simultaneously during face-to-face meeting. It aims to increase the quality of students' learning.

Blended learning is not unfamiliar in this educational era. For schools that are located in remote areas, there are many advantages offered while implementing this learning method. Face-to-face interaction which is done once a week certainly saves our time, money, and energy. The students do not have to pay for going to school, and save the cost of learning quota. The students also get proper and comfortable teaching because they are guided individually by the teachers. Basically, the implementation of blended learning in Junior High School is quite different from that in University. Looking how teachers as our reasearch participants conduct blended learning, it is a good step for them to do face-to-face interaction because students in Junior High School tend to be more dependent learning and are not more adaptable to this kind of learning rather than those in University. In summary, one of the benefits when implementing this learning method in remote areas is that it is wellorganized and relatively pays attention to students. Teaching and learning media in this method are relative. It means the media used can be accessed and students get all learning materials. In this context, blended learning could be one appropriate learning method that can be implemented during remote learning in remote areas.

\section{Another teaching strategy, besides blended learning, that we used during remote learning is home visit. \\ Both strategies gives us (teacher and students) the opportunity to communicate with each other. $(\mathrm{N})$}

The need of teachers to find out students' learning development is by conducting home visit programs. The teachers come to their students' house to advise students and their parents on the learning progress they experience. The teachers believe they need to work together with parents to control the students. The teachers have established ties with students and their parents through home visit activities. These program are believed to build positive relationship, especially, between teachers and students that give good impacts for students' learning. Without solid relationship and trust among them, no good learning outcome and no quality learning will happen. However, if positive relationship is created, it will help students keep engaging in learning, encourage best behaviour, and develop students self-worth. When the teachers have positive interaction, praise the students, and give them positive feedback, the students are directly motivated and give more attention on learning that may potentialy produce good learning outcomes. Positive relationship also helps teacher to improve students behaviour. The teacher can share about their personal lives in order to allow students to know them and the students likewise. So they will feel more comfortable and receptive. For this reason, it is important that sudents in Junior High School have good role model, namely their teachers to emulate and shape their good behaviour. As a result, these conditions produce good learning environment where every student feels wanted, appreciated, and loved. And then students feel more confident taking risk and pushing their intellect to higher levels. As teachers, they can also observe, interview, and listen to their students' problems related to learning facilities, materials, and completing the assignment given. In other words, home visit activities are their effort in building positive relationship between teachers and students during remote learning environment, and the result of these activities can be an evaluation of teaching learning system. The importance of building relationship between teachers and students was also declared by Varga (2017). He comments that a positive relationship between teachers and students is fundamental in succeeding teaching and learning process.

In addition, the advantages of home visit activity or program for young students have been reported by many schools or educational institutions. For examples, a school in Washington DC has 
implemented home visit program. The program has been claimed very beneficial since it has successfully improved attendance, reading proficiency and parent engagement for children in more than 12,000 families visited. Moreover, another report also states that the Parent Teacher Home Visits (PRHV) organization has the same opinion that this strategy can reduce inaccurate assumptions among teachers and help them build relationships with families.

The teaching strategies above have been carried out by the English teachers of junior school in Aranio. Those certainly provide opportunities and enable their students to remain connected while studying from home. In addition, for the teachers, this remote learning environment with many complex elements in it has been considered as one interesting individual experience that can be shared with other teachers with the same condition. Although the strategies surely have some limitedness, those all they can do to keep up with the condition now.

The findings of this study go hand in hand with several studies. One study concerning distance learning remote areas is conducted by Rayuwati (2020). She states that some handicaps appearing during implementing remote learning are experienced by students specially those in remote areas. Moreover, Adnan \& Anwar (2020) claim that distance learning could not produce desired result since the vast majority of the students are not capable of accessing the internet. They also highlight some issues on the lack of face-to-face interaction with teachers, response time and absence of traditional classroom socialization in implementing remote learning. Furthermore, a study conducted by (Octaberlina et al., 2020) declare that providing online class is one of the difficulties in implementing virtual English teaching. Another study completed by (Ferri et al., 2020) also reveals similar findings. They claim that the unreliability of internet connectios and students' lack of electronic devices are the technological challenges which exist in emergency remote teaching and learning. The results of those studies indicate the same major issue in remote learning environment.

\section{CONCLUSION}

The purpose of this study is to expose the challenges and the teaching strategies used by the English junior high school teachers of remote area during implementing remote learning. The researchers explored the variety of ways in which the teachers work really hard to convey the lessons when there is no possibility for online teaching and learning activities. Location might be required as the main consideration in implementing remote learning and it is still one major issue for them. The challenges faced by the participants of this research indicate that implementing remote learning in remote areas needs more considerations and efforts. Despite their efforts, there certainly remains limitedness. Nevertheless, other teachers in many other different remote areas could adopt their ideas and adjust them to their environment. Further research is required to explore how remote learning in remote areas is implemented and how they experience remote learning within that condition.

In relation to the context of this study, the findings suggest that the schools must provide supporting remote learning facilities so that students have their best learning experience. Besides, assessing students' learning and giving motivation when attending face-to-face interaction are needed to enhace education quality.

Also, a kind suggestion is given to many other researchers to find out some potential ways to deal with the implementation of remote learning in remote areas where internet access is still as the major issue.

\section{ACKNOWLEDGEMENT}

The researchers would like to express their sincere gratitude to some parties including the teachers and colleagues for their valuable support and help while conducting the research and producing this research paper. Hopefully, the result will give positive contribution to the educational development and the readers.

\section{REFERENCES}

Abdallah, Salam. (2009). Learning with Online Activities: What Do Students Think About Their Experience?. International Journal of Web-Based Learning and Teaching Technologies, Volume 4, Issue 2. https://doi.org/10.4018/jwltt.2009040101

Adnan \& Anwar (2020). Online learning amid the COVID-19 Pandemic: Students' Perspectives. Journal of Pedagogical Sociology and Psychology, vol. 2, no. 1, 45-51. https://doi.org/10.33902/JPSP.2020261309 
Belastock, E. (2020, July 21). How to Improve Remote Learning Experiences. https://edtechmagazine.com/k12/article/2020/07/how-improve-remote-learningexperiences

Carpenter, D. \& Dunn, J. (2020). We're All Teachers Now: Remote Learning During COVID-19. $\begin{array}{lllll}\text { Journal of School } & \text { Choice, } & \text { Vol.14 } & \text { No.4, }\end{array}$ https://doi.org/10.1080/15582159.2020.1822727

Ferri, Fernando., Grifoni, Patrizia., \& Guzzo, Tiziana. (2020). Online Learning and Emergency Remote Teaching: Opportunities and Challenges in Emergency Situation. Institute for Research on Population and Social Policies, National Research Council. https://doi.org/10.3390/soc10040086

Filgona, Jacob., Sakiyo, John., Gwany, D.M., \& Okoronka, A.U. (2020). Motivation in Learning. Asian Journal of Education and Social Studies, 10(4): 16-37. https://doi.org/10.9734/ajess/2020/v10i430273

Kistner, Saskia., Rakoczy, Katrin., Otto, Barbara., Klieme, Eckhard., Buttner, Gerhard. (2015). Teaching Learning Strategies: The Role of Instructional Context and Teacher Beliefs. Journal for Educational Research Online, Volume 7 (2015), No.1, 176-197.

Lubis, M.J., \& Sari, L.P. (2020). The Online Learning Activities During The COVID-19 Pandemic. BIRCI-Journal, Vol.3 No.4. https://doi.org/10.33258/birci.v3i4.1407

Macintyre \& Macdonald. (2011). Remote from What? Perspectives of Distance Learning Students in Remote Rural Areas of Scotland. International Review of Research in Open and Distance Learning, Vol.12.4. https://doi.org/10.19173/irrodl.v12i4.847

Ministry of Education and Culture. (2020). Circular Number 4 of 2020 on Implementation of Education Policy in Emergency during the COVID-19 Spread

Merriam, S.B. (1998). Qualitative Research and Case Study Applications in Education. Jossey-Bass.

Munir. (2017). Pembelajaran Digital. Alfabeta.

Nguyen, T. (2015). The Effectiveness of Online Learning: Beyond No Significant Difference and Future Horizons. MERLOT Journal of Online Learning and Teaching, Vol. 11 No.2

Octaberlina, L.R., Anggarina, I.F., \& Muslimin, A.I. (2020). Virtual English Teaching in Remote Area. Journal of Critical Reviews, ISSN 2394-5125 Vol. 7

Paolini, Allison. (2015). Enhancing Teaching Effectiveness and Student Learning Outcomes. Journal of Effective Teaching, Vol.15 No.1, page 20-33.

Pratiwi, H.T., \& Chasanah, L.N. (2018). Kajian Konseptual Blended Learning Berbasis Web Dapat Meningkatkan Hasil Belajar Siswa. Paper presented at Seminar Nasional Pendidikan 2018.

Ray, K. (2020, March 31). What is Remote Learning?. https://www.techlearning.com/how-to/whatis-remote-learning

Rayuwati. (2020). How Educatonal Technology Innovates Distance Learning During Pandemic Crisis in Remote Areas in Indonesia?. International Research Journal of Management, IT \& Social Sciences, Vol. 7 No. 6161-166. https://doi.org/10.21744/irjmis.v7n6.1032

Rizaldi \& Fatimah. (2020). How the Distance Learning can be a Solution during the Covid-19 Pandemic. International Journal of Asian Education (IJAE), Vol.01 No.3. https://doi.org/10.46966/ijae.v1i3.42

Rugg, Deborah. (2010). An Introduction To Triangulation. UNAIDS

Simonson, M., \& Seepersaud, D.J. (2018). Distance Education: Definition and Glossary of Terms, 4th Edition. IAP.

Surat Keputusan Bupati Banjar. (2013). Perubahan Keputusan Bupati Banjar Nomor 581 Tahun 2012 Tentang Penetapan Satuan Pendidikan Yang Berlokasi Di Daerah Khusus Di Wilayah Kabupaten Banjar.

Torrey, T. (2018). Why Do We Need Technology in Education?. Journal of Digital Learning in Teacher Education, Volume 34 Number 2. https:// doi.org/10.1080/21532974.2018.1442073

Varga, M. (2017). The Effect of Teacher-Student Relationship on The Academic Engagement of Students. Goucher College. 